Dep. of Bacteriology,

Animal Health Research Institute, Mansoura Laboratory.

\title{
STUDY ON SOME BACTERIAL CAUSES OF RESPIRATORY, ALIMENTARY AND MORTALITY DISEASES IN NEONATE LAMBS
}

(With 4 Tables)

\section{By}

\section{M.M. ABD-EL-LATIF; A.H. MOUSTAFA; M.K. REZIK} and M.A.S. MOUSTAFA*

* Dep. of Bacteriology, Animal Health Research Institute,

Zagazig Laboratory.

(Received at 5/4/2009)

دراسة عن بعض المسببات البكتيرية للأمراض التنفسية والهضمية والتفوق التهم

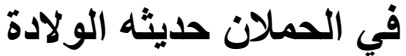

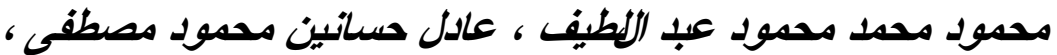

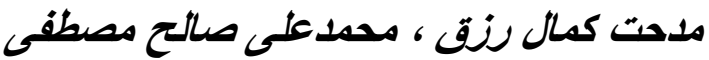

أجريت هذه الدراسة لمعرفة بعض المسببات البكتيرية المصاحبة للنفوق المبكر في الحملان

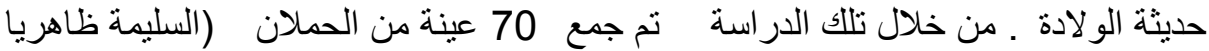

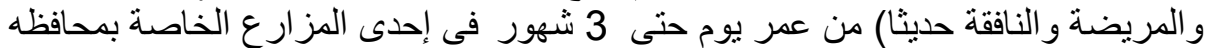

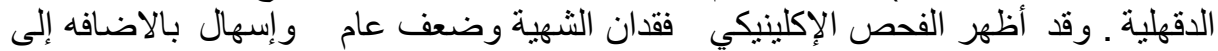

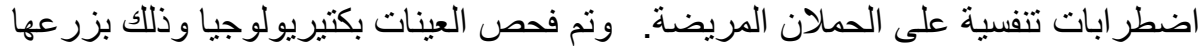

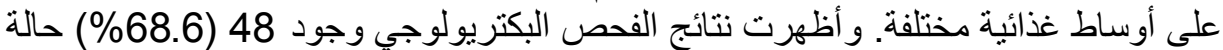

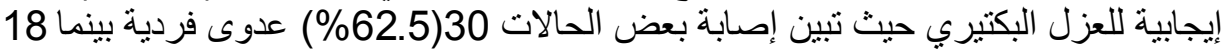

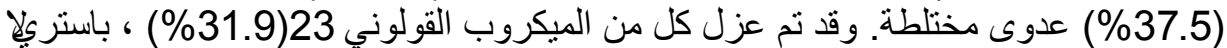

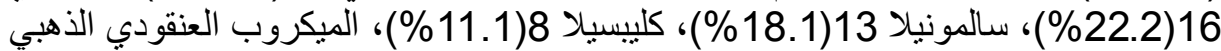

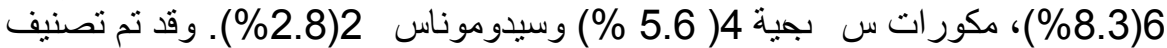

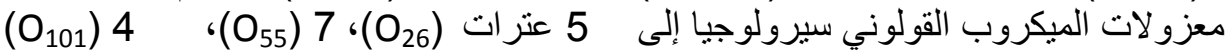

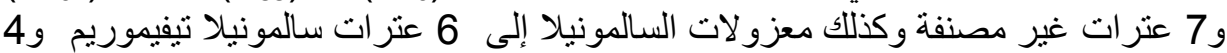

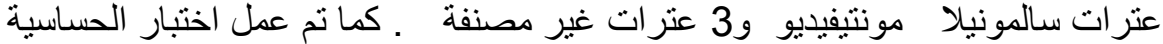

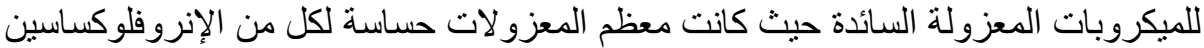

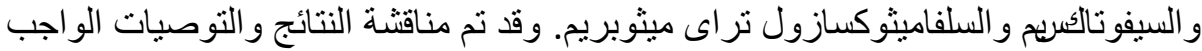
إتباعها لتجنب الإصابة بهذه الميكروبات وللمحافظة على الكئر الحالة الصحية للحملان. 
The present study was aimed to investigate the bacterial causes of newly born lamb mortalities. Seventy samples were collected (20 apparently healthy, 40 diseased and 10 dead lambs) their age ranged from one day up to 3 months old. The clinical symptoms of diseased lambs were weakness, partial loss of appetite, diarrhoea and respiratory signs. The bacteriological examination revealed that 48 samples $(68.6 \%)$ were positive for bacterial isolation and $30(62.5 \%)$ and $18(37.5 \%)$ were single and mixed infection respectively. E. coli was isolated at incidence percentage 23(31.9\%), Pasturella spp. 16(22.2\%), Salmonella spp. 13 (18.1\%), Klebsiella spp. 8(11.1\%), Staphylococcus aureus 6(8.3\%), Streptococcus spp. 4(5.6\%) and Pseudomonas spp. 2(2.8\%). E.coli isolates were identified serologically into $5\left(\mathrm{O}_{26}\right), 7\left(\mathrm{O}_{55}\right), 4\left(\mathrm{O}_{101}\right)$ and 7 untyped strains. Also, @Salmonella spp. was identified as 6 S. typhimurium, 4 S. montividio and 3 untyped strains. In vitro sensitivity test of isolated strains revealed that the most effective antibiotic were sensitive for Enrofloxacin, Cefotaxim and Trimethoprim sulfamethaxazole and should be used in treatment of diseased cases.

Key words: Lambs, mortality, respiratory, disorders, enteritis

\section{INTRODUCTION}

Early mortality of lambs is a major constraint on total sheep productivity. This problem is not a simple one, as it is not related to a specific cause but is the result of many factors attributable to climatic conditions, environmental stress, genetic influences, nutritional and infection causes (Nash et al., 1996).

The major causes of death in lambs were pneumonia, digestive problems (Diarrhoea), endoparasitic infestations, starvation and septicemia (Mukasa- Mugerwel et al., 2000). Bekele et al. (1992) and Abdel hadi et al. (2006) they observed that pneumonia and enteritis were from the commonest causes of high proportional morbidity and mortality rates between the lambs (Mishra et al., 2000).

Respiratory disorders caused by bacterial infections were considered as leading cause of lamb death among grazing sheep (Rowland et al., 1992; Haziroglu et al., 1994 and Martin 1996). Diarrhoea is still the most common and costly disease affecting neonatal small ruminants (Pugh, 2002 and Andres et al., 2009).

Many organisms were incriminated as causative agents of diarrhoea and death in newly born lambs after natural and experimental infections (Karmy and Ragab, 1983 and Munoz et al., 1996). The most 
important bacterial causes of pneumonia and and diarrhoea are E. coli, Salmonella spp., Pasteurella spp.,Klebsiella spp., Staphylococcus, Streptococcus and Pseudomonas spp. (Nesterov, 1981, Shegidevich et al., 1983, Leondidis et al., 1983 and Sharif et al., 2005). These pathogens are responsible for great mortality and various morbidity changes and at the same time contribute a hazard to public health (Orden et al., 2000 and Sharif et al., 2005).

The aim of this work is to isolate and identify some bacterial causes which recovered from both pneumonic, enteric cases and dead lambs. Determination of invitro antibiotic sensitivity of isolated organisms was also aimed.

\section{MATERIALS and METHODS}

\section{1- Animals:}

A total number of 70 samples newly born lambs (20 clinically healthy, 40 diseased and 10 dead lambs) from birth up to 3 months old of both sexes were located at a private farms in Dakahlia Governorate and subjected for clinical and laboratory investigations (Kelly, 1984).

\section{2- Samples:}

Samples from nasal and rectal swabs were collected from all cases. Other samples from liver, heart, lung, spleen, lymph nodes and small intestine were taken from dead ones under a septic conditions and sent without delay to the laboratory for bacteriological examination.

\section{3- Bacteriological examination:-}

The obtained samples were inoculated by sterile platinum loop in Nutrient, MacConkey and Selnite "F" broth and incubated at $37^{\circ} \mathrm{C}$ for 18 hr. and then subcultured into Nutrient agar, 5\% Blood sheep agar, S.S agar and MacConkey agar plates, then incubated over night at $37^{\circ} \mathrm{C}$. The produced colonies were prepared and stained with Gram stain, then examined microscopically for detection of morphological appearance, arrangement and staining reactions of the isolates (Cruickshank et al., 1982). Isolates thenafter were identified by biochemical tests (Edwards and Ewing 1972, Koneman et al., 1997 and Qunin et al., 2002).

\section{4- Serological identification of E.coli and Salmonella:}


a- E.coli: Serological identification of purified E.coli strains using available agglutinating Coli test sera (Behring merk, AG Marburg) was done according to manufacturer's instruction ( Lab, Germany).

b- Salmonella: The biochemically identified Salmonella strains were subjected for serological identification as described by Edwards and Ewing (1972), and the instruction of the manufacturer (Denken Selken Co. LTD, Tokyo, Japan).

5- Invitro antibiotic sensitivity test: The disc diffusion technique was performed on the isolated bacteria using Muller-Hinton (Oxoid 1998).

Ten chemotherapeutic discs were kindly supplied by Oxoid and namely: Enrofloxacin, Amoxycillin, Ampicillin, Gentamycin, Strepomycin, Cefotaxim, Erythromycin, Colistin sulphate, Oxytetracycline and Trimethoprime sulphamethexazole.

\section{RESULTS}

Clinical signs: The main clinical signs encountered for diseased lambs were depression, off food, emaciation and diarrhoea (either mucoid or bloody). In some cases difficult breathing, sneezing and nasal discharge.

Postmortem lesion: Dead lambs showed the following lesions: congestion of small and large intestines, congestion liver, kidneys and mesenteric lymph nods. In some cases there was congested lungs.

The results of bacteriological examination were recorded in Table 1, 2, 3 and 4.

Table 1: Results of bacteriological examination of obtained samples

\begin{tabular}{|l|c|c|c|c|c|c|c|c|}
\hline \multirow{2}{*}{ Source of samples } & $\begin{array}{c}\text { Total No. } \\
\text { of } \\
\text { examined } \\
\text { samples }\end{array}$ & \multicolumn{2}{|c|}{$\begin{array}{c}\text { Positive } \\
\text { samples }\end{array}$} & \multicolumn{2}{|c|}{$\begin{array}{c}\text { Single } \\
\text { isolates }\end{array}$} & \multicolumn{2}{|c|}{$\begin{array}{c}\text { Mixed } \\
\text { isolates }\end{array}$} & $\begin{array}{c}\text { Total } \\
\text { No. of } \\
\text { isolates }\end{array}$ \\
\cline { 3 - 9 } & No & $\%$ & No & $\%$ & No & $\%$ & \\
\hline $\begin{array}{l}\text { 1-Apparently } \\
\text { healthy lambs }\end{array}$ & 20 & 6 & 30.0 & 4 & 66.7 & 2 & 33.3 & 6 \\
2-Diseased lambs & 40 & 32 & 80.0 & 22 & 68.8 & 10 & 31.2 & 46 \\
3- Dead lambs & 10 & 10 & 100.0 & 4 & 40.0 & 6 & 60.0 & 20 \\
\hline \multicolumn{1}{|c|}{ Total } & 70 & 48 & 68.6 & 30 & 62.5 & 18 & 37.5 & 72 \\
\hline
\end{tabular}

Table2: Types of pathogenic bacteria recovered from examined samples 
Assiut Vet. Med. J. Vol. 55 No. 122 July 2009

\begin{tabular}{|c|c|c|c|c|c|c|c|c|}
\hline \multirow{3}{*}{ Bacterial isolates } & \multicolumn{6}{|c|}{ Condition of lambs } & \multirow{2}{*}{\multicolumn{2}{|c|}{ Total }} \\
\hline & \multicolumn{2}{|c|}{$\begin{array}{c}\text { Apparently } \\
\text { healthy lambs } \\
\left(20^{*}\right)\end{array}$} & \multicolumn{2}{|c|}{$\begin{array}{c}\text { Diseased } \\
\text { lambs } \\
(40 *)\end{array}$} & \multicolumn{2}{|c|}{$\begin{array}{c}\text { Dead } \\
\text { lambs } \\
\left(10^{*}\right)\end{array}$} & & \\
\hline & No. & $\%$ & No & $\%$ & No & $\%$ & No. & $\%$ \\
\hline E. coli & 2 & 10.0 & 14 & 35.0 & 7 & 70.0 & 23 & 31.9 \\
\hline Salmonella spp. & 0 & 0.0 & 8 & 20.0 & 5 & 50.0 & 13 & 18.1 \\
\hline Pasteurella spp. & 2 & 10.0 & 11 & 27.5 & 3 & 30.0 & 16 & 22.2 \\
\hline Klebsiella spp. & 0 & 0.0 & 6 & 15.0 & 2 & 20.0 & 8 & 11.1 \\
\hline Staph.aureus & 1 & 5.0 & 3 & 7.5 & 2 & 20.0 & 6 & 8.3 \\
\hline Streptococcus & 1 & 5.0 & 2 & 5.0 & 1 & 10.0 & 4 & 5.6 \\
\hline Pseudomonas spp. & 0 & 0.0 & 2 & 5.0 & 0 & 00.0 & 2 & 2.8 \\
\hline & 6 & & 46 & & 20 & & 72 & 100.0 \\
\hline
\end{tabular}

* No. of examined samples.

Table 3: Serological identification of isolated E. coli and Salmonella strains.

\begin{tabular}{|c|c|c|c|c|c|c|c|c|c|c|c|c|c|c|c|c|}
\hline \multirow{3}{*}{$\begin{array}{c}\text { Source of } \\
\text { Samples }\end{array}$} & \multicolumn{9}{|c|}{ (23) E. coli } & \multicolumn{7}{|c|}{ (13) Salmonella } \\
\hline & \multicolumn{2}{|c|}{$\mathrm{O}_{26}$} & \multicolumn{2}{|c|}{$\mathrm{O}_{55}$} & \multicolumn{2}{|c|}{$\mathrm{O}_{101}$} & \multicolumn{2}{|c|}{ Untyped } & \multirow[t]{2}{*}{ Total } & \multicolumn{2}{|c|}{$\begin{array}{c}S . \\
\text { typhimurium }\end{array}$} & \multicolumn{2}{|c|}{$\begin{array}{c}S . \\
\text { montividio }\end{array}$} & \multicolumn{2}{|c|}{ untyped } & \multirow[t]{2}{*}{ Tota } \\
\hline & No. & $\%$ & No & $\%$ & No. & $\%$ & No. & $\%$ & & No. & $\%$ & No. & $\%$ & No. & $\%$ & \\
\hline $\begin{array}{l}\text { App. } \\
\text { Healthy } \\
\text { lambs }\end{array}$ & 1 & 4.3 & 0 & 0.0 & 0 & 0.0 & 1 & 4.3 & 2 & 0 & 0.0 & 0 & 0.0 & 0 & 0.0 & 0 \\
\hline $\begin{array}{c}\text { Diseased } \\
\text { lambs }\end{array}$ & 2 & 8.7 & 5 & 21.7 & 3 & 13.1 & 4 & 17.4 & 14 & 2 & 15.4 & 2 & 15.4 & 1 & 7.7 & 5 \\
\hline $\begin{array}{l}\text { Dead } \\
\text { lambs }\end{array}$ & 2 & 8.7 & 2 & 8.7 & 1 & 4.3 & 2 & 8.7 & 7 & 4 & 30.7 & 2 & 15.4 & 2 & 15.4 & 8 \\
\hline Total & 5 & 21.7 & 7 & 30.4 & 4 & 17.4 & 7 & 30.4 & 23 & 6 & 46.1 & 4 & 30.8 & 3 & 23.1 & 13 \\
\hline
\end{tabular}


Table 4: Invitro antibiotic susceptibility of important isolated bacteria

\begin{tabular}{|c|c|c|c|c|c|}
\hline $\mathrm{N}_{\text {Antibiotic agent }}^{\text {Organisms }}$ & E. coli & Salmonella & Pasteurlla & Klebsilla & $\begin{array}{l}\text { Staph. } \\
\text { aureus }\end{array}$ \\
\hline Enrofloxacin & +++ & +++ & ++ & +++ & +++ \\
\hline Amoxycillin $\quad 25 \mathrm{ug}$ & $\mathrm{R}$ & $\mathrm{R}$ & $\mathrm{R}$ & $\mathrm{R}$ & $\mathrm{R}$ \\
\hline Ampicillin & $\mathrm{R}$ & $\mathrm{R}$ & $\mathrm{R}$ & $\mathrm{R}$ & $\mathrm{R}$ \\
\hline Gentamycin & ++ & ++ & $\mathrm{R}$ & +++ & ++ \\
\hline Streptomycin & ++ & ++ & ++ & ++ & ++ \\
\hline Cefotaxim & +++ & +++ & +++ & +++ & +++ \\
\hline Erythromycin $15 \mathrm{ug}$ & $\mathrm{R}$ & $\mathrm{R}$ & $\mathrm{R}$ & $\mathrm{R}$ & $\mathrm{R}$ \\
\hline Colistin sulphate 10ug & ++ & ++ & $\mathrm{R}$ & ++ & ++ \\
\hline Oxytetracyclin $30 \mathrm{ug}$ & ++ & ++ & ++ & $\mathrm{R}$ & ++ \\
\hline $\begin{array}{l}\text { Trimethoprim-sulpha } \\
\text { methaxazole } 1.25-23.75 \mathrm{ug}\end{array}$ & +++ & +++ & ++ & ++ & +++ \\
\hline
\end{tabular}

$+++=$ Highly sensitive

$++=$ Moderately sensitive

$\mathrm{R}=$ Resistante

\section{DISCUSSION}

Neonatal lamb mortality represents an economic loss and welfare concern. Mortality in lambs can be provoked by a multitude of both infections and non infectious causes. A varieties of infectious pathogens were revealed from diseased and dead lambs mainly bacterial causes. (Mitchell and Link Later, 1983).

The bacteriological examination of 70 samples from lambs revealed $48(68.6 \%)$ positive bacterial infection, where $6(30.0 \%)$ from apparently healthy lambs, $32(80.0 \%)$ from diseased lambs and 10(100\%)from dead lambs Table (1).

On the other hand, Ibrahim and Selim (2003) isolated the pathogenic bacteria from apparently healthy, diseased and dead lambs with percentage of $20 \%, 66.7 \%$ and $78.3 \%$ respectively. Khadr et al. (2006) isolated Campylobacter spp. with percentage of $12.3 \%$ from diseased lambs and $7.5 \%$ from apparently healthy lambs. Also Hala and Amany (2007) isolated Salmonella spp. from healthy and diseased lambs with percentage $4.7 \%$ and $12.7 \%$ respectively. Concerning the results in table (2) for the incidence of pathogenic bacteria in examined lambs results indicated that E.coli 23 (31.9\%), Pasteurella spp. 16 (22.2\%), Salmoenlla spp 13(18.1\%), Klebsiella spp. 8 (11.1\%), Staphylococcus aureus 6 (8.3\%), Streptococcus spp. 4 (5.6\%) and Pseudomonas spp. 2 
(2.8\%). It appears that the most prevalent bacteria were E. coli, Pasteurella spp., Salmonella spp.

This agreed with results reported by Sharif et al. (2005) who recorded that the bacteria responsible for neonatal mortality were E.coli, Pasteurella and Staph. aureus, also E. coli was the most frequent bacteria identified as a cause of neonatal mortality in lambs.

Results in Table (3) revealed that E. coli serotypes identified as 5 (21.7\%) $\mathrm{O}_{26}, 7(30.4 \%) \mathrm{O}_{55}, 4(17.4 \%) \mathrm{O}_{101}$ and 7 (30. 4\%) untybed strains. This result seems in accordance with those reported by Rao and Char, (1983) who isolated $E$. coli serotypes $\mathrm{O}_{26}$ and $\mathrm{O}_{55}$ from pneumonic lung of septicemic lambs, Duff and Hunt (1989) also isolated E.coli strain $\mathrm{O}_{101}$ from 4 day old dead lambs. Salmonellosis is a very important disease of lambs causing enteritis and septicemia, Salmonella is potentially lethal to lambs (Moredun Foundation, 2007). Also it is constitute a hazard to public health as all serovares can produce diseases to human (WHO, 2006). The results given in Table (3) revealed that 13 Salmonella strains recovered from examined samples were serotyped as: $6(46.1 \%)$ S.typhimurium as the most one, 4 (30.8\%) S.montividio and 3 (23.1\%) untyped strains. This resultis similar with those of Hala and amany (2007) who recorded that S.typhimurium was the most predominant isolate from dead lambs. On other hand Soumaya and Fadel (2004) isolated S.dublin and S. enteridis from dead lambs. The data presented in Table (4) showed that most isolates were highly sensitive to Enrofloxacin, Cefotaxim and Trimethoprim sulphamethaxazole and resistance to Ampicillin, Amoxycillin and Erythromycin.

Hatem et al. (2003) mentioned that the bacterial isolates from diseased sheep and goats were sensitive to Ciproflaxocin, Danofloxacin and Enrofloxacin and resistance to Ampicillin,Gentamycin and Trimethoprim -sulphamethaxazole.

Finally we could conclude that the most mortality rate between the newly born lambs due to pneumonia and diarrhoea. Also the most prevalent bacterial isolates are E.coli, Salmonella and Pasteurlla spp. So adequate hygienic measures and proper management may reduce the degree of animals exposure to disease producing agents.

\section{REFERENCES}

Abdel Hadi, S.A.; Niar, A.; Abdelhadi, F.Z.; Smail, N.L. and Ouzrout, R. (2006): Perinatal lamb mortalities on the level of Tiaret area (Algeria). Assiut Vet. Med. J. 52(109): 191-197. 
Andres, S.; Jimenez, A.; Sanchez, J.; Alonso, J.; Gomez, L.; Lopez, F. and Rey, J. (2009): Evaluation of some etiological factors predisposing to diarrhoea in lambs in La Serna (Southwest Spain). Small Ruminant Research, 70, (2), 272-275.

Bekele, T.; Kasali, O.B. and Woldeab, T. (1992): Causes of lamb morbidity and mortality in the Ethiopian highlands. Vet. Res. Commun.16 (6): 415-24.

Cruickshank, R.; Duguid, J.P.; Marmoni, B.P. and Swain, R.H. (1982): Medical Microbiology. $12^{\text {th }}$ Ed. Churonill Livingestone Edinburg, London, UK.

Duff, J.P. and Hunt, B.W. (1989): Lamb die from porcine E.coli. Vet. Rec. 125(15): PP. 404.

Edwards, P.R. and Ewing, W.H. (1972): Identificationof Enterobacteriacae, $3^{\text {rd }}$ edition. Burgeon Publishing Company, Atlanta, USA. P 103-104.

Hala, S. Ibrahim and Amany, H. El-Gohary (2007): Prevalence of Salmonella in sheep and its environment with reference to detection of virulence associated gene using PCR. Vet. Med. J. Giza. 55 (4): 1035-1051.

Hatem, M.E.; Mona, S.; Zaki Osman, A.H. and Mona El-Shabrawy (2003): Bacteriological, Histopathological and clinicopathological studies on respiratory affection in sheep and goats in Egypt. J. Egypt. Vet. Med. Assoc., 63(1): 97-109.

Haziroglu, R.; Diker, K.S.; Gulbahar, M.Y.; Akan, M. and Guvenc, T. (1994): Studies of the pathology and microbiology of pneumonic lungs of lambs. Dtsch Tierarztl Wochenschr. 101(11): 441-3.

Ibrahim, E.M. and Selim, A.M. (2003): Pathological and bacteriological studies on an outbreak of pneumonia pasteurellosis in sheep at Sharkia Province. Egypt. J. Agric. Res., 81(1): 33-49.

Karmy, S.A. and Ragab, A.M. (1983): Bacteriological examination of newly born lambs with enteric affection in Aswan Governorate. Agri. Res. Review, No. 7, Vol. 61.

Kelly, W.R. (1984): Veterinary Clinical Diagnosis, $3^{\text {rd }}$ Ed. Bailliare Tindal, London.

Khadr, A.M.; Haggag, Y.N. and Khaleil, S.A. (2006): Prevalence of Campylobacter jejuni and Campylobacter coli in calve and lambs with and without diarrhoea and their public health importance. Assiut Vet. Med. J. 52 (109): 179-190. 
Koneman, E.W.; Allen, S.D.; Danda, W.M.; Sohrechenberger, P.C. and Winn, W.C. (1997): Colour Atlas and Textbook of Diagnostic Microbiology. $4^{\text {th }}$ Ed. J.B. Lippincott Co., U.S.A

Leondidis, S.; Christopoulos, C.; Burlzihtzopoulov, E.; Sarris, K. and Xenos, G. (1983): Abortion and losses of new born lambs and kids duo to Salmonella spp. Priority aspects of Salmonellosis research. Aworkshop held in Brussel, 11-13 October.

Martin, W.B. (1996): Respiratory infections of sheep. Comp Immunol Microbiol Infect Dis. 19 (3): 171-9.

Mishra, N.; Mishra, S.; Pawaiya, RVS. and Bhagwan, PSK. (2000): Isolation and characterization of pasteurella hemolytica from a field outbreak in sheep of Rajasthan. Indian. J. of Animal Sciences. 70 (5): 443-445.

Mitchell, G. and Link Later, K. (1983): Differential diagnosis of scouring in lambs. In practice. 5(1) :4-12.

Moredun Foundation (2007): Pentlands Science Park, Bush Loan, Penicuik, Midlothian, EH26 OPZ, Scotland. Telephon01314455111, International +4413144455111,: Info @ moredun.Org. UK'".

Mukasa-Mugerwal, E.; Lahlou-Kassi, A.; Anindo, D.; Rege, J.E.; Tembely, S.; Tibbo, M. and Baker, R.L. (2000): Between and within breed variation in lamb survival and the risk factors associated with major causes of mortality in indigenous Horro and Menz sheep in Ethiopia. Small Rumin. Res., 37(1-2): 1-12.

Munoz, M.; Alvarez, M.; Lanzar and Carmines, P. (1996): Role of enteric pathogens in the a etiology of neonatal diarrhoea in lambs and goat kids in Spain.Epidemiology and Infection, 117(1): 203-211.

Nash, M.L.; Hungerford, L.L.; Nash, T.G. and Zinn, G.M. (1996): Risk factors for perinatal and postnatal mortality in lambs. Vet Rec.139 (3): 64-7

Nesterov, N.A. (1981): Streptococcal polyartheritis in lambs. Veterinariya Moscow (6), 40-41.

Orden, J.A.; Ruiz-Santa-Quiteria, J.A.; Garcia, S., Cid-D and De La Fuente, R. (2000): Quinolone resistance in Eschericia coli strains from diarrhoeic lambs in Spain. Vet. Rec. 11; 147 (20): 576-578.

Oxoid, (1998): The Oxoid Manual. $8^{\text {th }}$ Ed. Publ. By Oxoid Limited Wade Road, Basingstoke Hampshire RG 248 PW. England. 
Pugh, D.G. (2002): Sheep and Goat Medicine. W.B. Saunders Company U.S.A. first edition.

Quinn, P.J.; Markey, B.K.; Carter, M.E.; Donnelly, W.J. and Leonard, F.C. (2002): Veterinary Microbiology and Microbial Disease. Blackwell, U.K.

Rowland, J.P.; Salman, M.D.; Kimberling, C.V.; Schweitzer, D.J. and Keefe, T.J. (1992): Epidemiologic factors involved in prenatal lamb mortality on four range sheep operations. Am. J. Vet. Res. 53(2): 262-7.

Rao, P. and Char, N.L. (1983): Colibacillosis in lambs and its zoonatic significance. Indian Vet. J. 60 (11):870-872.

Sharif, L.; Obeidat, J. and Al-Ani, F. (2005): Risk factors for lamb and kid mortality in sheep and goat farms in Jordan. Bulgarian. J. of Vet. Med., 8(2): 99-108.

Shegidevich, E.A.; Fedotov, V.B. and Kryuchkov, Y.V. (1983): Serotypes of Pasteurlla multocida associated with lamb mortality. Trudy Veseoyuznogo Instituta Exsperimental noi Veterinarii, 58, 15-19.

Soumaya, S.A. El-Shafii and Fadel, N.G. (2004): Bacteriological study on salmonella abortion in savaolak sheep with special reference to pathological alteration in different organs of aborted faeti and dead newly born lambs. J. Egypt Vet. Med. Assoc. 64(4): 33-51.

World Health Organization, WHO (2006): "Drug resistant Salmonellafact sheet. No139" Revised April (2005). 